\title{
Undersowing wheat with different living mulches in a no-till system. I. Yield analysis
}

\author{
Matthieu CAROF ${ }^{\mathrm{a}}$, Stéphane de TourdonNET ${ }^{\mathrm{a} *}$, Patrick SAUlas $^{\mathrm{b}}$, Dominique LE FlOch $^{\mathrm{a}}$, Jean RogER-ESTRADE ${ }^{\mathrm{a}}$ \\ a AgroParisTech, UMR211, INRA/AgroParisTech, 78850 Thiverval-Grignon, France \\ ${ }^{\mathrm{b}}$ INRA, UMR211, INRA/AgroParisTech, 78850 Thiverval-Grignon, France
}

(Accepted 14 March 2007)

\begin{abstract}
The classical management of no-till wheat has several environmental and economic drawbacks such as the use and cost of herbicides, and the degradation of soil physical quality. Recent investigations suggest that undersowing crops with a living mulch could be a sustainable alternative. Therefore, we studied during three growing seasons the effect of undersowing wheat with living mulches on wheat grain yield. Treatments were wheat grown on a conventionally-tilled soil, on a no-till soil, and on a no-till soil with various living mulches. The living mulches were red fescue, sheep's fescue, alfalfa, bird's-foot-trefoil, black medic and white clover. Our results show that the use of living muches during wheat cropping decreased wheat yield of $19-81 \%$ by comparison with wheat cropped alone. This decrease is linked to the biomass of living mulches and weeds at the time of flowering. As a consequence, the control of living mulch and weed biomass is a major issue. Our findings also reveal that the wheat yield decrease is mainly the consequence of a decrease in grain number from 37 to 32 grains per spike on average, and of a decrease in spike number from 0.7 to 0.4 spikes per stem. We thus conclude that stem elongation, flowering and fecundation are the major stages of stress for wheat grown with living mulches. Our findings will help to design innovative crop management systems that take into account the biological interactions in agro-ecosystems better.
\end{abstract}

no-tillage / undersowing / winter wheat (Triticum aestivum L.) / leguminous and grass living mulches / grain yield / yield components

\section{INTRODUCTION}

Crop management systems based on little or no soil disturbance along with a permanent soil cover are of primary interest to help settle several economic and environmental issues of agriculture (Hatfield and Karlen, 1994; Ferron and Deguine, 2005; Lacas et al., 2005; Scopel et al., 2005). For example, no-till management systems lower fossil fuel consumption, enhance carbon sequestration and lessen soil erosion (Basic et al., 2004; Holland, 2004). Although environmental conditions of winter wheat (Triticum aestivum L.) are different in no-till systems compared with conventional-till ones (Tebrügge and Düring, 1999; Ferreras et al., 2000; Wright and Hons, 2005), they generally do not reduce wheat grain yield in temperate climates (Baumhardt and Jones, 2002; Anken et al., 2004). However, no-till production of wheat may present some short-term drawbacks. Weed control is known to be more challenging with no-tillage (Bàrberi and Lo Cascio, 2001), and it may increase herbicide use and costs (Sánchez-Gíron et al., 2004). Furthermore, Lampurlanés and Cantero-Martínez (2003) have reported that no-tillage lessens soil physical quality. To overcome these drawbacks, one possibility is to associate no-tillage with the use of a living mulch.

Living mulch is a plant species (annual or perennial) that is grown with the cash crop (Hartwig and Ammon, 2002). While the cash crop is harvested, the living mulch remains on

\footnotetext{
*Corresponding author: stephane.de_tourdonnet@agroparistech.fr
}

the field even during the off-growing season. A living mulch is used to provide beneficial services to the agro-ecosystem, including taking up excess soil nutrients, and improving soil physical characteristics along with weed and pest control, as well as augmenting biological diversity (Hartwig and Ammon, 2002; Nakamoto and Tsukamoto, 2006). Furthermore, if the living mulch is a leguminous one, it fixes nitrogen and thus may decrease fertiliser use during the cash crop growth cycle. Finally, the presence of a living mulch which is photosynthetically active all year long may improve carbon sequestration. The primary constraint of using living mulch in no-till wheat management systems is the ensuing competition for nutrients, light and/or water between the wheat and the living mulch, perhaps lowering the cash crop yield. Compared with a conventionally-tilled system, Samarajeewa et al. (2005) have shown wheat yield reduction in a no-till system with Chinese milk vetch (Astragalus sinicus L.) used as a living mulch. White and Scott (1991) have also reported that wheat yield decreases in no-till management systems with different living mulch species. Consequently, improving no-till management systems with a living mulch requires alleviating detrimental effects of the living mulch on wheat while enhancing advantages.

The purpose of this study was to determine the influence of tillage and living mulch on wheat production over three oneyear growing seasons in France. As we hypothesised that the degree of competition between the wheat and the living mulch depended on the living mulch species, six no-till treatments 
with a living mulch were compared with a conventionallytilled treatment and a no-till one. The present article examines the resulting wheat grain yield and its components. Based on the same experiment, a companion article presents competition relationships for light and nitrogen between the wheat and the different living mulches that help explain the differences in wheat yield according to treatment (Carof et al., 2007).

\section{MATERIALS AND METHODS}

\subsection{Site description}

A field trial was conducted from 2002 to 2005 at the INRA experimental station of Grignon, France $\left(48.9^{\circ} \mathrm{N}, 1.9^{\circ} \mathrm{E}\right.$, $130 \mathrm{~m}$ elevation, $606 \mathrm{~mm}$ annual 30-year average rainfall) on an Orthic Luvisol (FAO-UNESCO, 1974) with $250 \mathrm{~g} \mathrm{~kg}^{-1}$ clay, $500 \mathrm{~g} \mathrm{~kg}^{-1}$ silt and $250 \mathrm{~g} \mathrm{~kg}^{-1}$ sand in the topsoil. During wheat-growing seasons, precipitations were particularly low: (i) from February 10, 2003 to April 20, 2003, with $31 \mathrm{~mm}$ vs. $107 \mathrm{~mm}$ on the 30-year average, (ii) from January 30, 2004 to March 3, 2004, with $4 \mathrm{~mm}$ vs. $51 \mathrm{~mm}$ on the 30-year average, (iii) from May 9, 2004 to May 28, 2004, with $1 \mathrm{~mm}$ vs. $42 \mathrm{~mm}$ on the 30-year average, and (iv) from February 14, 2005 to March 20, 2005, with $6 \mathrm{~mm}$ vs. $48 \mathrm{~mm}$ on the 30-year average. Prior to this trial, the site had been conventionally cultivated for several years with annual ploughing. The whole area was ploughed one last time in November 2001.

\subsection{Experimental design}

The study labelled as experiments (1,2 and 3) three wheatgrowing seasons of the ongoing field trial. Experiment 1 was a wheat crop grown from October 21, 2002 to July 17, 2003. Experiment 2 was a wheat crop grown from October 29, 2003 to July 26, 2004. Experiment 3 was a wheat crop grown from October 18, 2004 to July 14, 2005.

Eight combinations of soil tillage and living mulch managements were maintained from November 2001: a conventionally-tilled management and seven variations on a no-till one. Conventionally-tilled management entailed an autumnal mouldboard ploughing to a $25-\mathrm{cm}$ depth, followed by two rotary harrowings to a $10-\mathrm{cm}$ depth for final seedbed preparation. The no-till management variations included a notill treatment without a living mulch and six no-till treatments with a living mulch. The six living mulch species were broadcast on March 28, 2002 and are as follows: sheep's fescue (Festuca ovina L.), red fescue (Festuca rubra L.), bird's-foottrefoil (Lotus corniculatus L.) and black medic (Medicago lupulina L.), all sown at a rate of $1.8 \mathrm{~g} \mathrm{~m}^{-2}$; alfalfa (Medicago sativa L.) sown at a rate of $2.0 \mathrm{~g} \mathrm{~m}^{-2}$; white clover (Trifolium repens $\mathrm{L}$.) sown at a rate of $0.6 \mathrm{~g} \mathrm{~m}^{-2}$. No-till/living mulch treatments were labelled using initials based on the scientific name of each living mulch species. In no-till treatments with or without a living mulch, soil disturbance was limited to a $3-\mathrm{cm}-$ deep by 4-cm-wide band corresponding to the direct driller. Whatever the treatment, crop residues were left on the field and chopped. Treatments were established on $9.0-$ by $6.0-\mathrm{m}$ plots. Each treatment was replicated four times. This experimental design allows us to study (i) the effect of soil tillage, comparing the conventionally-tilled treatment with the no-till treatment without a living mulch, and (ii) the effect of living mulch, comparing the no-till/living mulch treatments with the no-till treatment without a living mulch.

\subsection{Management practices}

A no-till drill (Semeato S/A, Brazil) with a row spacing of $17 \mathrm{~cm}$ was used for sowing wheat seeds (cultivar Isengrain) on all plots at a rate of 220 seeds $\mathrm{m}^{-2}, 270$ seeds $\mathrm{m}^{-2}$ and 270 seeds $\mathrm{m}^{-2}$ for experiments 1,2 and 3 , respectively. Before wheat seeding, conventionally-tilled plots were mouldboard ploughed and rotary harrowed. Whatever the plot, wheat was protected against fungus diseases and pests. Grains were harvested 269 days after sowing, 271 days after sowing and 269 days after sowing for experiments 1,2 and 3, respectively.

Whatever the experiment, the amount of $\mathrm{NH}_{4} \mathrm{NO}_{3}$ fertiliser applied was calculated thanks to the nitrogen balance-sheet method to meet wheat and living mulch nitrogen requirements (Rémy and Hébert, 1977), leading to applying various levels of fertiliser between treatments due to different living mulch nitrogen requirements. In experiment $1,200 \mathrm{~kg} \mathrm{ha}^{-1}$ of nitrogen were applied on two dates on all plots. In experiment 2, $220 \mathrm{~kg} \mathrm{ha}^{-1}$ of nitrogen were applied on three dates on all plots, with the exception of the grass ones $\left(255 \mathrm{~kg} \mathrm{ha}^{-1}\right.$ of nitrogen applied on four dates). In experiment 3 , nitrogen applications were as follows: $225 \mathrm{~kg} \mathrm{ha}^{-1}$ of nitrogen applied on three dates on the plots without a living mulch; $260 \mathrm{~kg} \mathrm{ha}^{-1}$ of nitrogen applied on three dates on the grass plots; $200 \mathrm{~kg} \mathrm{ha}^{-1}$ of nitrogen applied on three dates on the leguminous plots, with the exception of the alfalfa ones $\left(235 \mathrm{~kg} \mathrm{ha}^{-1}\right.$ of nitrogen applied on three dates). Before wheat seeding, living mulch growth was slowed down by the use of (i) a herbicide in the grass treatments (experiments 2 and 3 ) and in the leguminous ones (experiments 1 and 3), and (ii) a mower in the leguminous treatments (experiment 2). In experiment 1 , no herbicide was used after wheat seeding to observe living mulch influence on weed populations. In experiments 2 and 3, herbicides were used during the wheat growth cycle to kill weeds and to slow down living mulch growth. For each treatment, the herbicide strategy (chemical type, rate and number of weed-killer applications) was chosen according to the weed population observed in the plots as well as the biology of the living mulch species (data not shown).

\subsection{Data collection and calculation}

For each experiment, sampling took place at three particular wheat stages: the end of tillering, flowering and physiological maturity. Wheat plants and their tillers were counted at the end of tillering in two subplots of three $0.5-\mathrm{m}$ length rows $\left(0.25 \mathrm{~m}^{2}\right.$ area) per plot. After averaging subplots, plant stand was reported as plants per square metre, and the number of tillers per 
plant was the ratio between the tiller counts (tiller $\mathrm{m}^{-2}$ ) and the plant counts (plant $\mathrm{m}^{-2}$ ). Spikes were counted at physiological maturity in four subplots of three 0.5 -m length rows $\left(0.25 \mathrm{~m}^{2}\right.$ area) per plot. Then, spikes were clipped from plants, and grain yield was determined by threshing and weighing grains of each subplot (after drying for two days at $80{ }^{\circ} \mathrm{C}$ ). Finally, grains of each subplot were counted. After averaging subplots, the number of spikes per tiller was the ratio between the spike counts (spike $\mathrm{m}^{-2}$ ) and the tiller counts (at the end of tillering). The number of grains per spike was the ratio between grain counts (grain $\mathrm{m}^{-2}$ ) and spike counts. Grain yield was reported as grams per square metre on a $150 \mathrm{~g} \mathrm{~kg}^{-1}$ moisture basis. The grain weight, reported as g grain ${ }^{-1}$, was calculated as the ratio between grain yield and grain counts. Aboveground biomass of living mulch and weeds was determined at the end of tillering and at flowering by sampling two subplots of $0.25 \mathrm{~m}^{2}$ per plot. Samples were weighed after oven-drying for two days at $80^{\circ} \mathrm{C}$. After averaging subplots, biomass of living mulch and weeds was reported as $\mathrm{g} \mathrm{m}^{-2}$. Plant disease and insect population were regularly monitored during the wheat growth cycle.

\subsection{Statistical analysis}

Data from all the experiments were analysed by means of the general linear model procedure available from SAS/STAT (SAS Institute Inc., 1999). Experiment, treatment within an experiment and block within an experiment were designated as fixed effects. Mean comparisons based on the least-squares mean (LSMEANS) statement were made to separate treatments within an experiment where $P$-values indicated that significant differences existed $(P \leqslant 0.05)$. Linear regression between (i) grain yield and grain $\mathrm{m}^{-2}$, (ii) grain $\mathrm{m}^{-2}$ and spike $\mathrm{m}^{-2}$, (iii) spike $\mathrm{m}^{-2}$ and tiller $\mathrm{m}^{-2}$, (iv) tiller $\mathrm{m}^{-2}$ and plant $\mathrm{m}^{-2}$, and (v) grain yield and biomass of living mulch and weeds was determined by a regression procedure, available from SAS/STAT, over all the experiments as well as within each experiment.

\section{RESULTS AND DISCUSSION}

\subsection{Wheat grain yield}

For any given experiment, the treatments without a living mulch resulted in very similar yield and presented the highest yield in comparison with the no-till/living mulch treatments (Fig. 1). The yields of the conventionally-tilled treatment and the no-till one were 461 and $503 \mathrm{~g} \mathrm{~m}^{-2}$ for experiment 1,752 and $792 \mathrm{~g} \mathrm{~m}^{-2}$ for experiment 2 and 876 and $818 \mathrm{~g} \mathrm{~m}^{-2}$ for experiment 3 , respectively. While the yield of experiment 2 was rather similar to the yield of experiment 3 , it differed significantly from the yield of experiment $1(P \leqslant 0.05)$. Changes in climatic conditions over the growing seasons may explain yield variance between experiments as the number and length of dry periods during the wheat growth cycle were less and less important from experiment to experiment.
Whatever the experiment, undersowing wheat with a living mulch generally reduced wheat grain yield compared with sole crop, but ranking of the no-till/living mulch treatments was not constant from experiment to experiment. In experiment 1 , yield of the no-till/living mulch treatments was significantly reduced compared with the no-till treatment without a living mulch and three of the six no-till/living mulch treatments (wheat $\times$ alfalfa, wheat $\times$ red fescue and wheat $\times$ sheep's fescue) exhibited particularly low yield, less than $200 \mathrm{~g} \mathrm{~m}^{-2}$, the lowest level out of the three experiments. In experiment 2, three groups were evident: the no-till treatments with bird'sfoot-trefoil and sheep's fescue as a living mulch presented yields close to that for the no-till treatment without a living mulch; the no-till treatment with red fescue as a living mulch presented a yield significantly lower than that of the no-till treatment without a living mulch; and the no-till treatments with alfalfa, black medic and white clover as a living mulch presented yields significantly lower than those of all the other treatments. In experiment 3, yields of the no-till/living mulch treatments were close, except for the yield of the no-till treatment with sheep's fescue as a living mulch, which was significantly lower than the yields of the no-till treatments with alfalfa, bird's-foot-trefoil and white clover as a living mulch.

Whatever the no-till/living mulch treatment, yield variance from experiment to experiment was related to a decrease in living mulch and weed biomass at flowering (Fig. 2), especially due to herbicidal managements. Finally, in our experiments, undersowing wheat with a living mulch led to grain yield reduction compared with sole crop, undoubtedly because of competition for environmental resources. This competition depended on the interaction between living mulch species and experiments, i.e. climatic conditions and management practices. Nevertheless, the association of undersowing with notillage was possible since some treatments, depending on the experiment, presented yields close to that of the no-till treatment without a living mulch.

In this short-term study, whatever the experiment, wheat grain yield of the conventionally-tilled treatment was similar to that of the no-till treatment without a living mulch. Consequently, under our environmental conditions, soil tillage had no effect on wheat yield. However, this finding cannot be applied generally to no-till systems in equilibrium as our notill treatment without a living mulch was in the transition period from mouldboard ploughing to no-till. Insufficient time without ploughing had elapsed for soil structural change that could have disturbed crop environmental conditions (Kinsella, 1995).

Yield reduction for no-till/living mulch treatments has been observed by other authors. In a two-year experiment without herbicides during the wheat growth cycle, White and Scott (1991) studied the effects of various leguminous living mulches on no-till wheat. Among the living mulches were alfalfa, bird's-foot-trefoil and white clover. These no-till/living mulch treatments had little effect on wheat yield during the first wheat-growing season, whereas they greatly reduced wheat yield during the second growing season. Yield interannual variations were attributed, in part, to the greater growth of the living mulches during the second growing season: on 

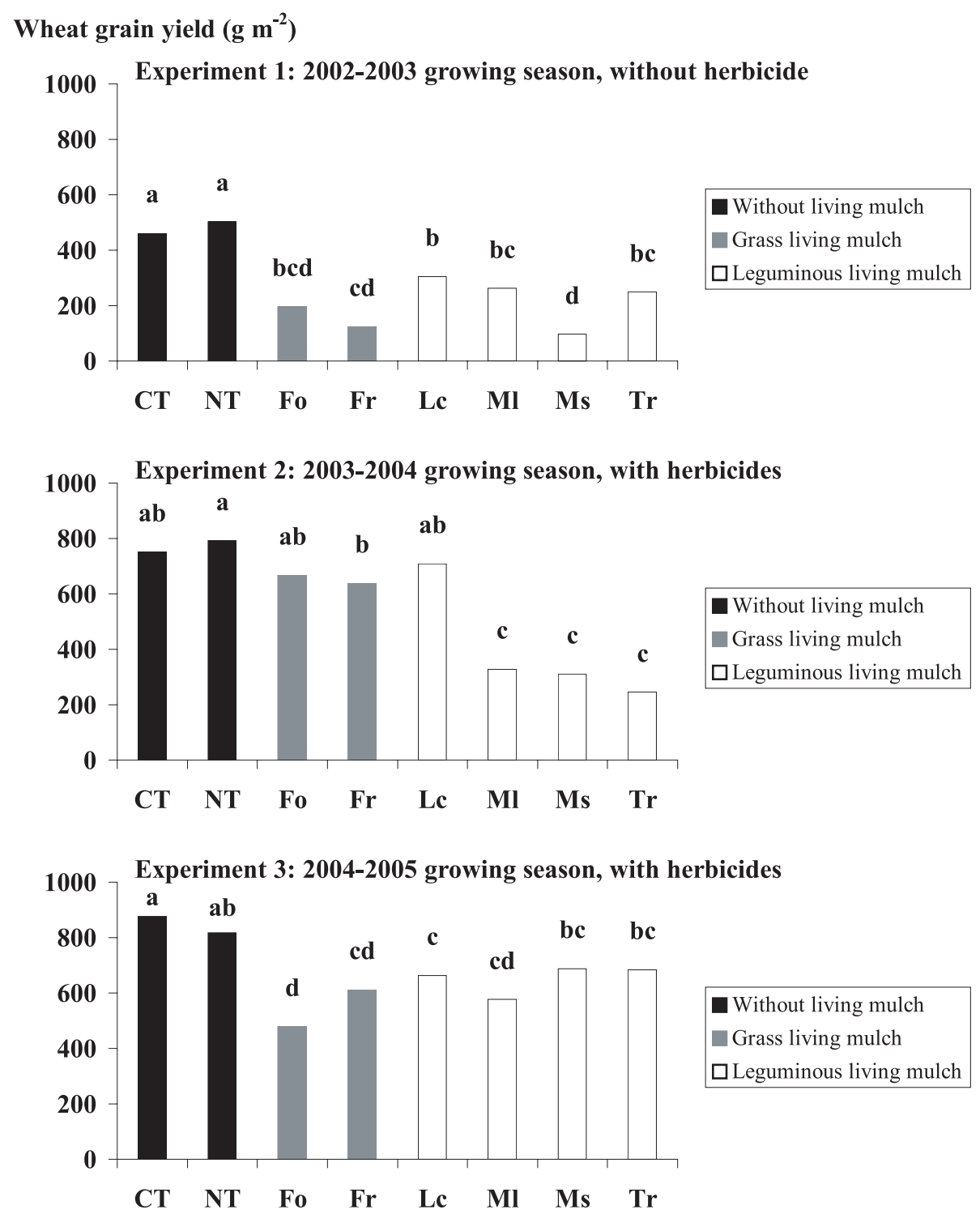

Figure 1. Effect of soil tillage and living mulch on wheat grain yield for three experiments $(1,2,3)$. Treatments are: conventionally-tilled wheat (CT); no-till wheat without a living mulch (NT); no-till wheat undersown with sheep's fescue (Fo), red fescue (Fr), bird's-foot-trefoil (Lc), black medic (Ml), alfalfa (Ms) and white clover (Tr). Mean of four replicates. Within an experiment, treatments followed by the same letter are not significantly different (LSMEANS, $P \leqslant 0.05$ ).

the one hand, it significantly reduced weed biomass but on the other hand, without herbicides, it resulted in a strong competition between the living mulch and the wheat, reducing its yield. Humphries et al. (2004) found that intercropping wheat with alfalfa reduced grain yield, despite herbicidal management. However, they showed that the productivity of intercropping might be improved if growth patterns of wheat and alfalfa were separated by using a winter-dormant variety of alfalfa. In a two-year experiment, Thorsted et al. (2006) reported that mechanical control of white clover with a weed brusher improved wheat yield compared with an unbrushed clover. However, intercrop wheat yield was still below sole crop yield. Our study confirmed that improving herbicidal strategy from experiment to experiment reduced wheat penalty, i.e. the gap between un- dersown wheat yield and sole crop yield. This is coherent with Teasdale (1996), who reported that even if a living mulch is weed-control effective, it also requires herbicidal and/or mechanical management to prevent excess competition with the cash crop.

\subsection{Yield components}

The objective here is to pursue a more in-depth yield analysis by studying yield components. For each treatment within an experiment, this allows for a ranking of the periods of the wheat growth cycle during which stresses, e.g. competition 

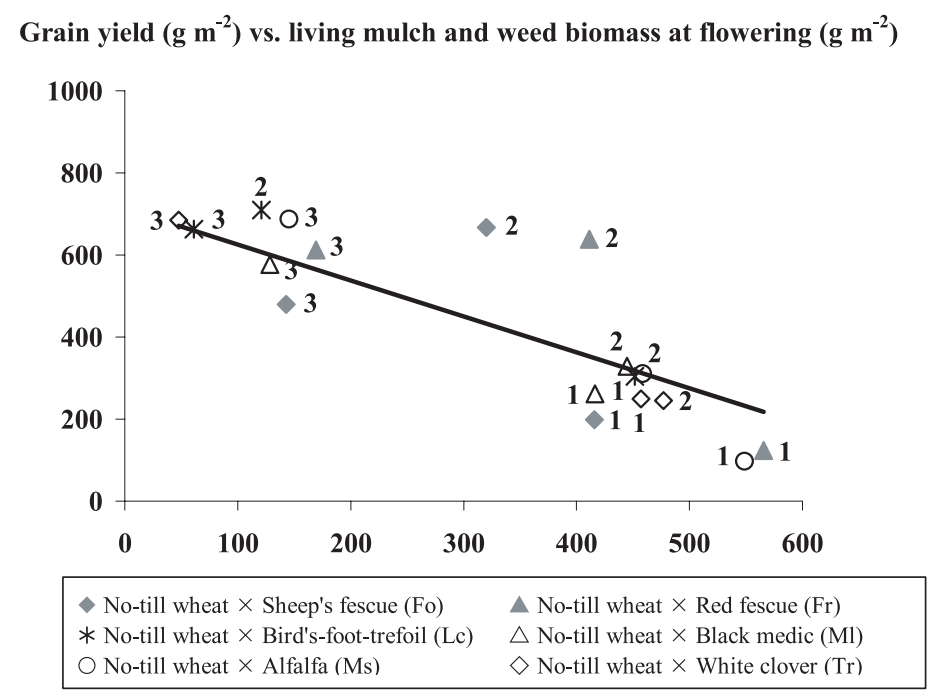

Figure 2. Effect of living mulch and weed biomass on wheat grain yield for three experiments $(1,2,3)$. Solid line was fitted by linear regression over all the experiments (grain yield $=-$ living mulch and weed biomass $+713 ; \mathrm{R}^{2}=0.52, P \leqslant 0.05$ ).

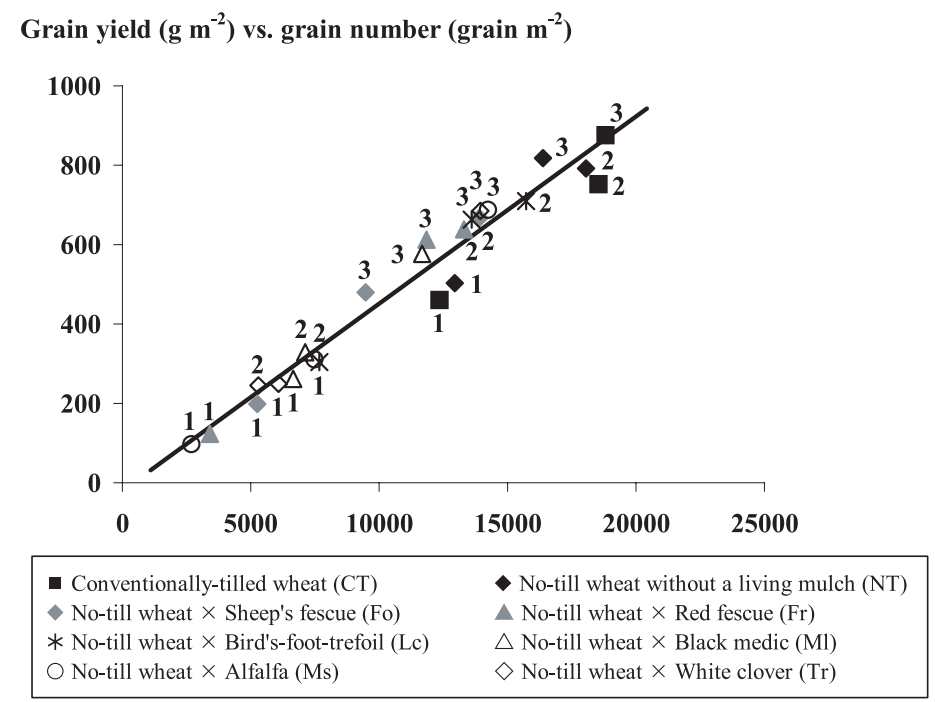

Figure 3. Effect of soil tillage and living mulch on grain-filling process: relationship between grain yield and grain number for three experiments $(1,2,3)$. Solid line was fitted by linear regression over all the experiments (grain yield $=0.05 \times$ grain number $-21 ; \mathrm{R}^{2}=0.96, P \leqslant 0.05$ )

of the living mulch with the wheat, occurred (Meynard and David, 1992; Leterme et al., 1994).

Whatever the experiment, wheat grain yield was highly related to the number of grains per $\mathrm{m}^{2}$ (Fig. 3): yield variations between treatments, described in the previous section, were mainly due to grain number variations, not to grain weight variations. On average, from experiment 1 to experiment 3, grain weight was $0.038 \mathrm{~g} \mathrm{grain}^{-1}, 0.045 \mathrm{~g} \mathrm{grain}^{-1}$ and $0.049 \mathrm{~g} \mathrm{grain}^{-1}$. Grain weight greatly increased from experiment 1 to experiment 2 due to a decrease in cumulative water deficit between these experiments during the grain-filling period, i.e. from June to July (data not shown). Whatever the experiment, grain weight of the no-till/living mulch treatments was similar to grain weight of the no-till treatment without a living mulch, with the exception of the two grass treatments in experiment 2. On the other hand, grains weighed less for the conventionally-tilled treatment compared with the no-till treatment without a living mulch, whatever the experiment: $0.037 \mathrm{~g}_{\text {grain }^{-1}}$ vs. $0.039 \mathrm{~g} \mathrm{grain}^{-1}$ (experiment 1), $0.041 \mathrm{~g}_{\text {grain }}{ }^{-1}$ vs. $0.044 \mathrm{~g} \mathrm{grain}^{-1}$ (experiment 2) and $0.047 \mathrm{~g} \mathrm{grain}^{-1}$ vs. $0.050 \mathrm{~g}_{\text {grain }^{-1}}$ (experiment 3). Although very low, grain weight variations between treatments without a living mulch were significant in experiments 2 and 3 (LSMEANS, $P \leqslant 0.05$ ). Finally, under our environmental conditions, grain weight variations between experiments and treatments mainly depended on climatic conditions, but not on the undersowing of wheat with a living mulch. As grain weight is primarily affected by stresses during the grain-filling period (Gooding et al., 2000), we concluded this period was not a sensitive one in the no-till/living mulch treatments, i.e. 
Grain number (grain $\mathrm{m}^{-2}$ ) vs. spike density $\left(\right.$ spike $\mathrm{m}^{-2}$ )

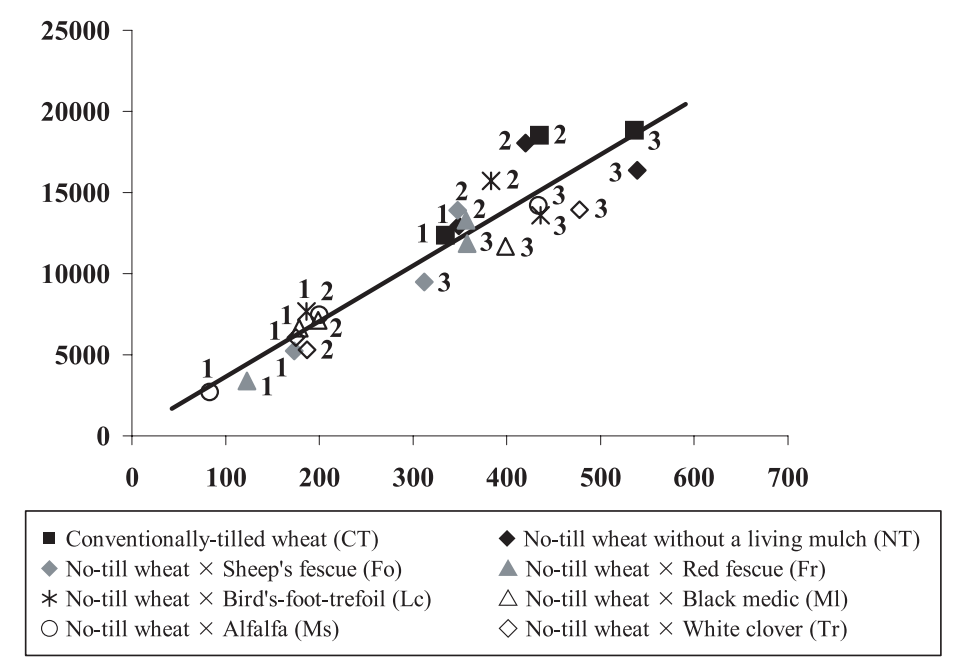

Figure 4. Effect of soil tillage and living mulch on flowering and fecundation processes: relationship between grain number and spike density for three experiments $(1,2,3)$. Solid line was fitted by linear regression over all the experiments (grain number $=34 \times$ spike density +192 ; $\left.\mathrm{R}^{2}=0.88, P \leqslant 0.05\right)$.

competition for environmental resources between the wheat and the living mulch did not occur during the grain-filling period, whatever the living mulch species.

Whatever the experiment, grain number per $\mathrm{m}^{2}$ was well related to spike number per $\mathrm{m}^{2}$ (Fig. 4). However, the relationship between these yield components differed from one experiment to another as regression of grain number per $\mathrm{m}^{2}$ against spike number per $\mathrm{m}^{2}$ deviated between experiments: R-square was $0.96(P \leqslant 0.05)$ for experiments 1 and 2 , whereas it was $0.83(P \leqslant 0.05)$ for experiment 3 . Consequently, grain production per spike was significantly contrasted from one experiment to another $(P \leqslant 0.05)$ : on average, it was 34 grains spike ${ }^{-1}, 38$ grains spike ${ }^{-1}$ and 32 grains spike $^{-1}$ for experiment 1 , experiment 2 and experiment 3 , respectively. Whatever the experiment, the number of grains per spike never differed significantly between treatments without a living mulch (LSMEANS, $P \leqslant 0.05$ ). On the other hand, in experiment 1 , grain production per spike for four out of the six no-till treatments with a living mulch (wheat $\times$ alfalfa, wheat $\times$ white clover, wheat $\times$ red fescue and wheat $\times$ sheep's fescue) was significantly lower than that for the no-till treatment without a living mulch (LSMEANS, $P \leqslant 0.05$ ), with 30 grains spike $^{-1}$ on average vs. 37 grains spike ${ }^{-1}$. In experiment 2 , four out of the six no-till treatments with a living mulch (wheat $x$ alfalfa, wheat $\times$ black medic, wheat $\times$ red fescue and wheat $x$ white clover) presented a number of grains per spike significantly lower than that for the no-till treatment without a living mulch (LSMEANS, $P \leqslant 0.05$ ), with 34 grains spike $^{-1}$ on average vs. 43 grains spike ${ }^{-1}$. In experiment 3 , undersowing wheat with a living mulch did not reduce grain production per spike when compared with sole crop. Grain production per spike mainly described the flowering and fecundation periods. Consequently, the flowering and fecundation periods were sensitive ones for most of the no-till/living mulch treatments in experiments 1 and 2, resulting in grains per spike reduction compared with sole crop. However, grain yield variations between treatments also depended on spike density.

The number of spikes per $\mathrm{m}^{2}$ was related to the number of tillers per $\mathrm{m}^{2}$ (Fig. 5). The relationship between these yield components varied from one experiment to another: R-square was $0.26(P \leqslant 0.05)$ for experiment $1,0.43(P \leqslant 0.05)$ for experiment 2 and $0.28(P \leqslant 0.05)$ for experiment 3 . As a result, the effect of treatment on spikes per tiller was significant and differed from one experiment to another. Whatever the experiment, the number of spikes per tiller did not vary significantly between treatments without a living mulch (LSMEANS, $P \leqslant 0.05$ ). However, undersowing wheat with a living mulch led to a decrease in spikes per tiller when compared with sole crop. This was significant for (i) three leguminous treatments (wheat $\times$ alfalfa, wheat $\times$ bird's-foot-trefoil and wheat $\times$ black medic) in experiment 1 , (ii) one leguminous treatment (wheat $\times$ alfalfa) in experiment 2 , and (iii) one leguminous treatment (wheat $\times$ black medic) in experiment 3 (LSMEANS, $P \leqslant 0.05$ ). Finally, the stem elongation period, described by the number of spikes per tiller, was a sensitive one for some leguminous treatments but not for the grass treatments.

The tiller number per $\mathrm{m}^{2}$ was determined by the plant stand (Fig. 6). The relationship between these yield components was not constant from experiment to experiment: R-square was $0.68(P \leqslant 0.05)$ for experiment $1,0.36(P \leqslant 0.05)$ for experiment 2 and $0.62(P \leqslant 0.05)$ for experiment 3 . Consequently, plant tiller production was contrasted from one experiment to another: it averaged 2.0 tillers plant ${ }^{-1}$ in experiment 1 , 3.1 tillers plant ${ }^{-1}$ in experiment 2 and 4.2 tillers plant $^{-1}$ in experiment 3 . The increase in plant tiller production from experiment to experiment was related to a decrease in living mulch and weed biomass at the end of tillering: on average, 


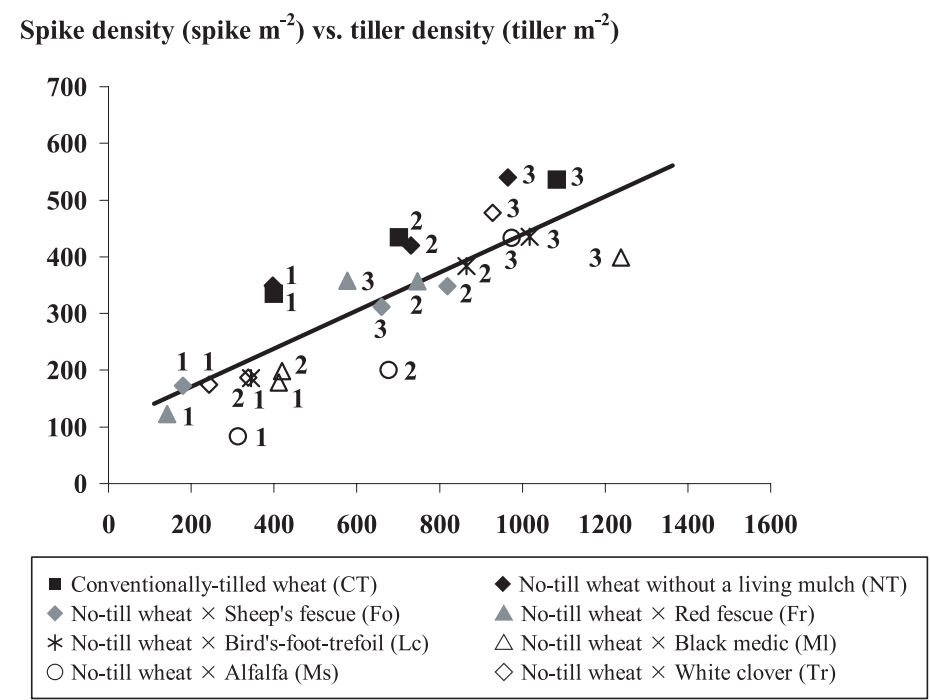

Figure 5. Effect of soil tillage and living mulch on stem elongation process: relationship between spike density and tiller density for three experiments $(1,2,3)$. Solid line was fitted by linear regression over all the experiments (spike density $=0.33 \times$ tiller density $+104 ; R^{2}=0.60$, $P \leqslant 0.05)$.

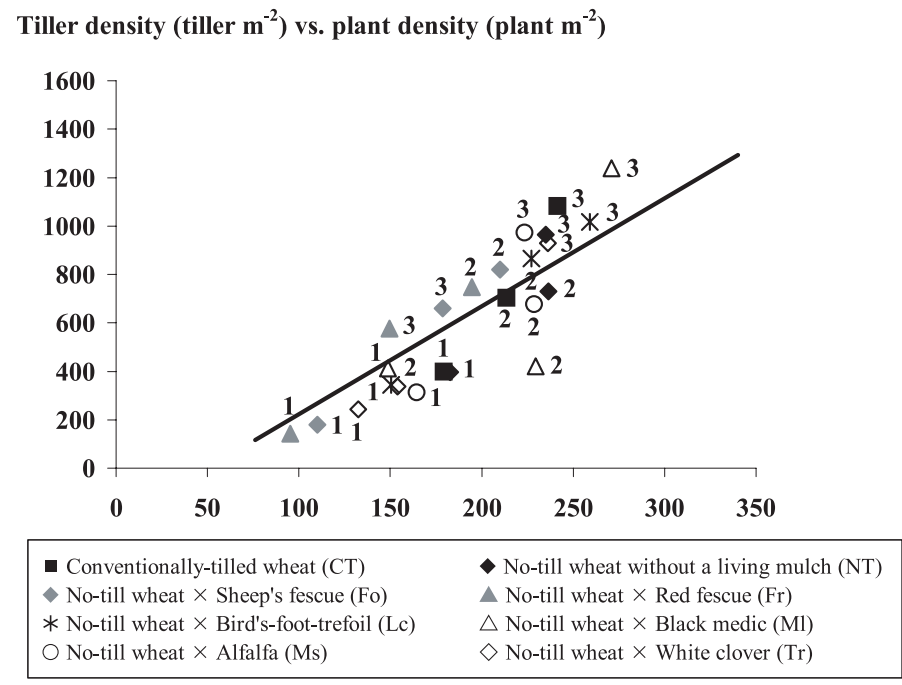

Figure 6. Effect of soil tillage and living mulch on tillering process and plant establishment: relationship between tiller density and plant density for three experiments $(1,2,3)$. Solid line was fitted by linear regression over all the experiments (tiller density $=4.5 \times$ plant density -224 ; $\left.\mathrm{R}^{2}=0.64, P \leqslant 0.05\right)$.

this biomass was $127 \mathrm{~g} \mathrm{~m}^{-2}$ in experiment $1,102 \mathrm{~g} \mathrm{~m}^{-2}$ in experiment 2 and $45 \mathrm{~g} \mathrm{~m}^{-2}$ in experiment 3 . Whatever the experiment, the effect of treatment on tillers per plant rarely differed significantly between treatments without a living mulch or between the no-till/living mulch treatments and the no-till treatment without a living mulch. In fact, only the no-till treatment with black medic as a living mulch in experiment 2 had a significant effect on the number of tillers per plant, which decreased down to 1.8 tillers plant $^{-1}$ (LSMEANS, $P \leqslant 0.05$ ). This decrease was mainly due to a population of Geranium spp. uncontrolled by the living mulch. All in all, whatever the treatment, tillering was rarely disturbed.

Plant stand varied from 95 plants $\mathrm{m}^{-2}$ to 271 plants $\mathrm{m}^{-2}$ (Fig. 6). Whatever the experiment, the number of plants per $\mathrm{m}^{2}$ never varied significantly between five out of the eight treatments (conventionally-tilled, no-till, wheat $x$ alfalfa, wheat $\times$ bird's-foot-trefoil and wheat $\times$ black medic). Conversely, the number of plants per $\mathrm{m}^{2}$ was low in some treatments. Compared with the no-till treatment without a living mulch, this was significant (LSMEANS, $P \leqslant 0.05$ ) for the two grass treatments in experiments 1 and 3 , and one leguminous treatment (wheat $\times$ white clover) in experiment 2 . In experiments 1 and 2 , the decrease in plant stand was related to a welldeveloped cover of the living mulches since the beginning of winter. In experiment 1 , growth of the grass living mulches was insufficiently slowed down by the use of herbicides before wheat seeding, contrary to the leguminous living mulches. In experiment 2, mowing white clover before wheat seeding was 
Table I. Effect of soil tillage and living mulch on wheat sensitivity periods to stresses for three experiments (1, 2, 3). Treatments are: conventionally-tilled wheat (CT); no-till wheat undersown with sheep's fescue (Fo), red fescue (Fr), bird's-foot-trefoil (Lc), black medic (Ml), alfalfa (Ms) and white clover (Tr). Minus sign, -, indicates significant reduction of a yield component compared with the no-till treatment without a living mulch. One minus sign is equal to a reduction of 0 to $20 \%$; two minus signs are equal to a reduction of 20 to $30 \%$, etc.

\begin{tabular}{|c|c|c|c|c|c|}
\hline & \multicolumn{5}{|c|}{ Yield component / Growth and development period } \\
\hline & Plants per $\mathrm{m}^{2}$ & Tillers per plant & Spikes per tiller & Grains per spike & Grain weight \\
\hline Treatment & Plant establishment & Tillering & Stem elongation & Flowering/fecundation & Grain filling \\
\hline \multicolumn{6}{|c|}{ Experiment 1 (2002-2003 growing season, without herbicide) } \\
\hline \multicolumn{6}{|c|}{$e_{2}$} \\
\hline Fo & ---- & & & -- & \\
\hline Fr & ---- & & & -- & \\
\hline Lc & & & --- & & \\
\hline Ml & & & ----- & & \\
\hline Ms & & & ------- & - & \\
\hline $\operatorname{Tr}$ & & & & - & \\
\hline \multicolumn{6}{|c|}{ Experiment 2 (2003-2004 growing season, with herbicides) } \\
\hline CT & & & & & - \\
\hline \multicolumn{6}{|l|}{ Fo } \\
\hline $\mathrm{Fr}$ & & & & - & \\
\hline \multicolumn{6}{|l|}{ Lc } \\
\hline M1 & & ---- & & -- & \\
\hline Ms & & & ---- & - & \\
\hline $\operatorname{Tr}$ & --- & & & --- & \\
\hline \multicolumn{6}{|c|}{ Experiment 3 (2004-2005 growing season, with herbicides) } \\
\hline CT & & & & & - \\
\hline Fo & -- & & & & \\
\hline $\mathrm{Fr}$ & --- & & & & \\
\hline $\mathrm{Lc}$ & & & & & \\
\hline Ml & & & ---- & & \\
\hline Ms & & & & & \\
\hline $\operatorname{Tr}$ & & & & & \\
\hline
\end{tabular}

not sufficient to slow down its growth until the beginning of winter. In experiment 3 , the decrease in plant stand noticed in the grass treatments was related to an attack of wheat bulb fly (Delia coarctata Fallen) observed during plant establishment.

Yield component analysis highlighted sensitivity periods to stresses according to treatment (Tab. I). What our results did show was that grain weight of conventionally-tilled treatment was reduced compared with that of no-till treatment without a living mulch. However, as wheat yield depends mainly on grains per spike and spikes per unit area (Donaldson et al., 2001), grain weight variations between treatments without a living mulch did not affect wheat yield. Norwood (2000) also noticed some grain weight variations according to soil tillage practices, without any yield reduction. However, in that study, the ranking of soil tillage practices was not constant from year to year: in the first year, grain weight tended to be higher in the no-till system, whereas in the sixth year, it tended to be higher in the conventional-till one. Another study of soil tillage effect on wheat yield components did not report any grain weight variation between soil tillage practices (Hemmat and Eskandari, 2004). In our short-term study, grains per spike, spikes per tiller, plant tiller production and plant stand did not differ between conventionally-tilled treatment and no-till treatment without a living mulch, whatever the experiment; there- fore, soil tillage had no effect on wheat growth and development from the seeding to the beginning of the grain-filling period. As previously said, this result cannot be applied generally to no-till systems in equilibrium.

Our results show that yield components disturbed by the presence of a living mulch were not the same from one experiment to another or from one treatment to another (Tab. I). Sensitivity periods to stresses were changed by the interaction between experiments and no-till/living mulch treatments, i.e. by the interaction between climatic conditions, herbicidal management of living mulch and weeds, and living mulch species. With the exception of the attack of wheat bulb fly, erratic plant establishment and erratic tillering occurred when living mulches and weeds were well-developed since the beginning of winter. In a companion article, we demonstrate that the decrease in plant number per $\mathrm{m}^{2}$ and plant tiller production was always related to competition for light between wheat and living mulches, coupled with competition for nitrogen in two situations (wheat $\times$ black medic and wheat $\times$ white clover in experiment 2) (Carof et al., 2007). The stem elongation period, as well as the flowering and fecundation periods, were sensitive ones for eleven out of the eighteen situations (i.e. in three experiments times six no-till/living mulch treatments), especially when a high level of living mulch and 
weed biomass was measured at flowering. The grain-filling period was not a sensitive one in the no-till/living mulch treatments. Many authors have reported grains per spike and spike density are the main determinants of wheat yield (McMaster et al., 1994; Jeuffroy and Bouchard, 1999; Donaldson et al., 2001), i.e. stresses which affect these components affect wheat yield. Under temperate climates, the number of grains per spike mainly decreases due to low radiation intercepted by the wheat around meiosis, as well as nitrogen deficiency (Demotes-Mainard et al., 1995; Jeuffroy and Bouchard, 1999). Spike density mainly decreases due to bad plant establishment and/or bad plant tiller production and/or tiller abortion, mainly caused by nitrogen deficiency (Masle, 1981a; Masle, 1981b), without neglecting diseases and pest attacks. In the companion article, we show that the decrease in grains per spike and spike density resulted from competition for light between wheat and living mulches due to light partitioning between mixed species (Carof et al., 2007). Furthermore, our results reveal that in experiment 1 , competition for light was coupled with competition for nitrogen.

\section{CONCLUSION}

First, the results of this study indicate that during the transition period from mouldboard ploughing to no-till, soil tillage did not affect wheat grain yield, even if wheat sensitivity to stresses might have been higher during the grain-filling period when the wheat crop was grown on a ploughed soil, inducing lower grain weight. Secondly, the results show that undersowing wheat with a living mulch reduced wheat yield in fourteen out of the eighteen situations. By using yield component analysis, we demonstrated that the ranking of contrasting notill/living mulch treatments for yield components was changed by the interaction between climatic conditions, living mulch species and management practices that were used to control the dynamics and biomass of living mulch and weeds. Finally, our study highlighted the fact that, in particular treatments and herbicidal managements (wheat $\times$ bird's-foot-trefoil and wheat $x$ sheep's fescue in experiment 2 , as well as wheat $x$ alfalfa and wheat $x$ white clover in experiment 3 ), the association of undersowing with no-tillage did not reduce wheat grain yield. The understanding of competitive relationships between the cash crop and the living mulch appear to be essential for preventing wheat losses in no-till/living mulch systems. Living mulches could then improve the positive effects of agriculture on the environment through the increase in carbon sequestration, biodiversity, soil organic matter, etc. Designing agro-ecosystems able to promote these biological regulations is a major issue.

Acknowledgements: We would like to thank G. Grandeau for his technical assistance with the field trial. We are grateful to R. Gosse, P.-E. Rouger and C. Souin for their help with the measurements. We thank T. Doré for his comments on the preparation of this article. We also thank S. Tanis-Plant for her editorial work in English.

\section{REFERENCES}

Anken T., Weisskopf P., Zihlmann U., Forrer H., Jansa J., Perhacova K., (2004) Long-term tillage system effects under moist cool conditions in Switzerland, Soil Till. Res. 78, 171-183.

Bàrberi P., Lo Cascio B. (2001) Long-term tillage and crop rotation effects on weed seedbank size and composition, Weed Res. 41, 325340.

Basic F., Kisic I., Mesic M., Nestroy O., Butorac A. (2004) Tillage and crop management effects on soil erosion in central Croatia, Soil Till. Res. 78, 197-206.

Baumhardt R.L., Jones O.R. (2002) Residue management and tillage effects on soil-water storage and grain yield of dryland wheat and sorghum for a clay loam in Texas, Soil Till. Res. 68, 71-82.

Carof M., de Tourdonnet S., Saulas P., Le Floch D., Roger-Estrade J. (2007) Undersowing wheat with different living mulches in a notill system II. Competition for light and nitrogen, Agron. Sustain. Dev. 27, 357-365.

Demotes-Mainard S., Doussunault G., Meynard J.-M. (1995) Effects of low radiation and low temperature at meiosis on pollen viability and grain set in wheat, Agronomie 15, 357-365.

Donaldson E., Schillinger W.F., Dofing S.M. (2001) Straw production and grain yield relationships in winter wheat, Crop Sci. 41, 100-106.

FAO-UNESCO (1974) Soil map of the world, 1:5 000 000, FAO, Roma (Italy).

Ferreras L.A., Costa J.L., Garcia F.O., Pecorari C. (2000) Effects of notillage on some soil physical properties of a structural degraded Petrocalcic Paleudoll of the southern "Pampa" of Argentina, Soil Till. Res. 54, 31-39.

Ferron P., Deguine J.-P. (2005) Crop protection, biological control, habitat management and integrated farming. A review, Agron. Sustain. Dev. 25, 17-24.

Gooding M.J., Dimmock J.P.R.E., France J., Jones S.A. (2000) Green leaf area decline of wheat flag leaves: the influence of fungicides and relationships with mean grain weight and grain yield, Ann. Appl. Biol. 136, 77-84.

Hartwig N.L., Ammon H.U. (2002) Cover crops and living mulches, Weed Sci. 50, 688-699.

Hatfield J.L., Karlen D.L. (1994) Sustainable agricultural systems, Lewis Publishers, CRC Press, Boca Raton, USA.

Hemmat A., Eskandari I. (2004) Tillage system effects upon productivity of a dryland winter wheat-chickpea rotation in the northwest region of Iran, Soil Till. Res. 78, 69-81.

Holland J.M. (2004) The environmental consequences of adopting conservation tillage in Europe: reviewing the evidence, Agr. Ecosyst. Environ. 103, 1-25.

Humphries A.W., Latta R.A., Auricht G.C., Bellotti W.D. (2004) Overcropping lucerne with wheat: effect of lucerne winter activity on total plant production and water use of the mixture, and wheat yield and quality, Aust. J. Agr. Res. 55, 839-848.

Jeuffroy M.-H., Bouchard C. (1999) Intensity and duration of nitrogen deficiency on wheat grain number, Crop Sci. 39, 1385-1393.

Kinsella J. (1995) The effects of various tillage systems on soil compaction, in: Soil and Water Conservation Society (Ed.), Farming for a better environment, ankeny, USA, pp. 15-17.

Lacas J.-G., Voltz M., Gouy V., Carluer N., Gril J.-J. (2005) Using grassed stips to limit pesticide transfer to surface water: a review, Agron. Sustain. Dev. 25, 253-266.

Lampurlanès J., Cantero-Martínez C. (2003) Soil bulk density and penetration resistance under different tillage and crop management 
systems and their relationship with barley root growth, Agron. J. 95, 526-536.

Leterme P., Manichon H., Roger-Estrade J. (1994) Yield analysis of wheat grown in an on-farm field network in Thymerais (France), Agronomie 14, 341-361.

Masle J. (1981a) Élaboration du nombre d'épis d'un peuplement de blé d'hiver en situation de compétition pour l'azote. I. Mise en évidence d'un stade critique pour la montée d'une talle, Agronomie 1, 623632.

Masle J. (1981b) Relations entre croissance et développement pendant la montaison d'un peuplement de blé d'hiver. Influence des conditions de nutrition, Agronomie 1, 365-374.

McMaster G.S., Wilhelm W.W., Bartling P.N.S. (1994) Irrigation and culm contribution to yield and yield components of winter wheat, Agron. J. 86, 1123-1127.

Meynard J.-M., David G. (1992) Diagnosis of crop yield elaboration, Cah. Agr. 1, 9-19.

Nakamoto T., Tsukamoto M. (2006) Abundance and activity of soil organisms in fields of maize grown with a white clover living mulch, Agr. Ecosyst. Environ. 115, 34-42.

Norwood C.A. (2000) Dryland winter wheat as affected by previous crops, Agron. J. 92, 121-127.

Rémy J.C., Hébert J. (1977), Le devenir des engrais azotés dans le sol, Comptes-rendus de l'Académie d'Agriculture Française 63, 700710 .
Samarajeewa K.B.D.P., Horiuchi T., Oba S. (2005) Weed population dynamics in wheat as affected by Astragalus sinicus L. (Chinese milk vetch) under reduced tillage, Crop Prot. 24, 864-869.

Sánchez-Gíron V., Serrano A., Hernánz J.L., Navarrete L. (2004) Economic assessment of three long-term tillage systems for rainfed cereal and legume production in semiarid central Spain, Soil Till. Res. 78, 35-44.

SAS Istitute Inc. (1999) SAS OnlineDoc( Version 8, SAS Institute Cary, NC.

Scopel E., Findeling A., Chavez Guerra E., Corbeels M. (2005) Impact of direct sowing mulch-based cropping systems on soil carbon, soil erosion and maize yield, Agron. Sustain. Dev. 25, 425-432.

Teasdale J.R. (1996) Contribution of cover crops to weed management in sustainable agricultural systems, J. Prod. Agr. 9, 475-479.

Tebrügge F., Düring R.A. (1999) Reducing tillage - a review of results from a long-term study in Germany, Soil Till. Res. 53, 15-28.

Thorsted M.D., Olesen J. Weiner J. (2006) Mechanical control of clover improves nitrogen supply and growth of wheat in winter wheat/white clover intercropping, Eur. J. Agron. 24, 149-155.

White J.G., Scott T.W. (1991) Effects of perennial forage-legume living mulches on no-till winter wheat and rye, Field Crop. Res. 28, 135148.

Wright A.L., Hons F.M. (2005) Tillage impacts on soil aggregation and carbon and nitrogen sequestration under wheat cropping sequences, Soil Till. Res. 84, 67-75. 